\title{
Hairy cell leukemia: a histo-cytochemical and ultra-structural study
}

Departments of Hematology and Electron Microscopy, Universidade Federal de São Paulo, Escola Paulista de Medicina - São Paulo, Brazil

\begin{abstract}
We studied five patients with hairy cell leukemia $(\mathrm{HCL})$ diagnosed within the last ten years at the Department of Hematology of Universidade Federal de São Paulo - Escola Paulista de Medicina. Our purpose was to analyze the value of transmission electron microscopy (TEM) by comparing this method with the conventional ones. At diagnosis, patients presented weight loss, spleen enlargement and hairy cells (HC) in peripheral blood and bone marrow slides. $\mathrm{HC}$ was characterized by morphology and tartrate test resistance in the acid phosphatase reaction (TRAP). At the evaluation time, the amount of $\mathrm{HC}$ ranged from $1 \%$ to $85 \%$ of WBC count. All patients, except two, had phenotype B. In these last two, TRAP as well as phenotype B could not be documented due to low HC numbers in their exams. Cytoplasmatic projections and the absence of lamellar ribosomic complex were the most frequent ultrastructural findings, even in those patients with the lowest $\mathrm{HC}$ numbers. Based on these features, TEM is an efficient method for searching for $\mathrm{HC}$ at $\mathrm{HCL}$ diagnosis and during the course of the disease.
\end{abstract}

UNITERMS: Hairy cell leukemia. Electron microscopy. Monoclonal antibodies. Histo-cytochemistry.

\section{INTRODUCTION}

$\mathrm{H}$ airy cell leukemia (HCL) is a rare chronic lymphoproliferative disorder characterized by neoplastic mononuclear cells with fine cytoplasmic projections. Patients present weight loss, splenomegaly and symptoms of pancytopenia. The degree of fatigue, lethargy and weakness varies according to the severity of the anemia (hemoglobin is generally between 7 and $10 \mathrm{~g} / \mathrm{dl})^{(1)}$. Hemorrhagic manifestations, such as

\section{Address for correspondence:}

Denize Gonsalez

Department of Hematology (UNIFESP-EPM)

Rua Botucatu, 740 - 3o andar - V. Clementino

São Paulo/SP - Brasil - CEP 04023-062 purpura and echymoses, caused by severe thrombocytopenia with peripheral blood plasma platelet counts of less than $80,000 / \mathrm{mm}^{3}$, are found in about $20 \%$ of patients ${ }^{(2)}$. Leucopenia (white counts less than 4,000/ $\mathrm{mm}^{3}$ ) is seen with a predominance of neoplastic cells ${ }^{(1)}$.

HCL is more common among whites and the male to female ratio is $4: 1$. The age of onset is between 22 and 79 years $^{(3)}$. The etiology of HCL remains obscure.

The disease is suspected when splenomegaly is observed without adenopathy or pancytopenia. Under optical microscopy, medium size circulating mononuclear cells with cytoplasmic projections are seen. The nuclei of these cells are often eccentric and granular. Diagnosis is confirmed by bone marrow aspirate with cells characteristically exhibiting tartrate-resistant acid phosphatase (TRAP) ${ }^{(4)}$. In the majority of cases, HCL cells have an immunological phenotype compatible with a Bcell lymphocyte origin ${ }^{(1,5)}$. 
Table 1

Characteristics of patients with HCL.

\begin{tabular}{|c|c|c|c|c|c|c|c|c|}
\hline Patient & $\begin{array}{c}\text { Age } \\
\text { (years) }\end{array}$ & Sex & Race & Clinical Features & $\begin{array}{l}\text { Diagnostic } \\
\text { Tests }\end{array}$ & $\begin{array}{c}\text { Time since } \\
\text { diagnosis (years) }\end{array}$ & $\begin{array}{l}\% \text { hairy } \\
\text { cells }\end{array}$ & $\begin{array}{l}\text { Previous } \\
\text { Treatment }\end{array}$ \\
\hline 1 & 62 & $M$ & W & $\begin{array}{l}\text { Weight loss } \\
\text { Splenomegaly } \\
\text { Pancytopenia }\end{array}$ & $\begin{array}{c}\text { BMB } \\
\text { TRAP (+) }\end{array}$ & 10 & 2 & Corticosteroid \\
\hline 2 & 64 & $\mathrm{~F}$ & W & $\begin{array}{l}\text { Splenomegaly } \\
\text { Anemia }\end{array}$ & $\begin{array}{c}\text { BMA } \\
\text { Splenectomy }\end{array}$ & 8 & 15 & Splenectomy \\
\hline 3 & 84 & M & W & $\begin{array}{l}\text { Weight loss } \\
\text { Splenomegaly } \\
\text { Pancytopenia }\end{array}$ & $\operatorname{FATR}(+)$ & 1 & 44 & None \\
\hline 4 & 48 & M & W & $\begin{array}{c}\text { Weight loss } \\
\text { Splenomegaly } \\
\text { Anemia } \\
\text { Leucopenia }\end{array}$ & $\begin{array}{c}\text { BMB } \\
\operatorname{TRAP}(+)\end{array}$ & 4 & 6 & Interferon \\
\hline 5 & 46 & $F$ & W & $\begin{array}{l}\text { Weight loss } \\
\text { Splenomegaly } \\
\text { Pancytopenia }\end{array}$ & $\begin{array}{c}\text { BMB } \\
\operatorname{TRAP}(+)\end{array}$ & $1 / 12$ & 42 & None \\
\hline
\end{tabular}

BMB - bone marrows biopsy; BMA - bone marrow aspirate; TRAP - tartrate-resistant acid phosphatase; W - White

This study was peformed on five patients with HCL in order to compare their data from transmission electron microscopy (TEM) with conventional morphology and cytochemistry of peripheral blood and bone marrow cells at diagnosis and evaluation time.

\section{MATERIALS AND METHODS}

The peripheral blood of five patients who had previously been diagnosed as having HCL was analyzed. Bone marrow aspirate and biopsy were performed on only one of the patients (patient 5), the others refused to undergo the procedure again (it had already been done at the time of initial diagnosis).

Blood smears and cytochemistry (PAS and TRAP) were performed using standard methods. The immunophenotype $\left(\mathrm{CD}_{3}, \mathrm{CD}_{7}, \mathrm{CD}_{19}\right.$ and $\left.\mathrm{SIg}\right)$ was identified by immunofluorescence. Although the co-expression of $\mathrm{CD}_{11 \mathrm{c}}, \mathrm{CD}_{22}$ and $\mathrm{CD}_{25}$ is highly specific to $\mathrm{HCL}^{(6)}$, these phenotypes were not tested for, due to a lack of appropriate reagents.

The material destined for evaluation by transmission electron microscopy was fixed in $2 \%$ glutaraldehyde in $0.1 \mathrm{M}$ cacodylate buffer ( $\mathrm{pH} 7.4$ ) for 2 hours and post-fixed with $1 \%$ osmium tetroxide. After dehydration, the material was embedded in araldite resin and sectioned using an ultramicrotome. This section was then stained with 5\% uranyl acetate and lead citrate before being examined with a Jeol EX 1200 electron microscope.

\section{RESULTS}

The study was undertaken between May and October 1993. Four patients had previously been diagnosed with HCL. Patient characteristics are shown in Table 1. The peripheral blood counts done at the time of this study are shown in Table 2, and cytochemistry and immunophenotype results are in Table 3.

Under optical microscopy, neoplastic cells were seen in the peripheral blood from all patients and the bone marrow aspirate and biopsy from patient 5. They were presented as mononuclear cells of intermediate size with many cytoplasmatic projections. The cytoplasm was basophilic and the nuclei were usually displayed peripherally, with an oval shape. The chromatin pattern was finely granular and nucleoli were rarely seen.

The ultrastructural studies from peripheral blood from all patients and from bone marrow aspirate and biopsy 


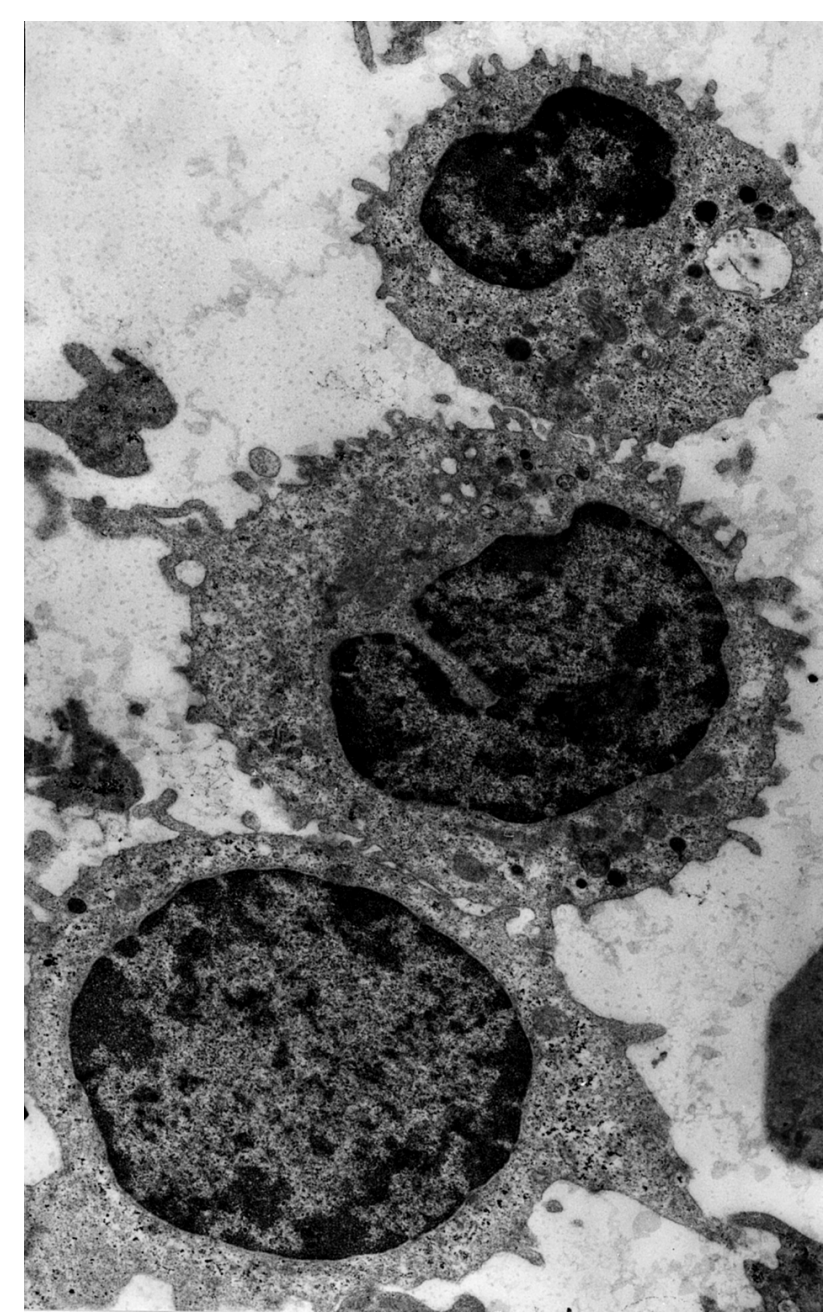

Figure 1 - Electron micrograph of three hairy cells in which are observed cytoplasmic projections, faint nuclear chromatin in the centre and dense chromatin adjacent to the nuclear membrane. The nuclei of the upper cells are dislocated to the periphery and present several organelles. The lower cell shows a large nucleus and few organelles (X 13000).

\section{Table 2}

Blood counts of patients with HCL, at time of evaluation.

\begin{tabular}{crrcccc}
\hline Patients & $\mathrm{Hb}(\mathrm{g} / \mathrm{dl})$ & $\mathrm{WB}$ & $\mathrm{G}(\%)$ & $\mathrm{L}(\%)$ & $\mathrm{Pl} \times 10^{5}$ & $\mathrm{HC}(\%)$ \\
\hline 1 & 15.0 & 7600 & 36 & 63 & 6.49 & 1 \\
2 & 12.4 & 5000 & 46 & 51 & 6.12 & 3 \\
3 & 9.0 & 5400 & 02 & 13 & 1.07 & 85 \\
4 & 7.2 & 4200 & 32 & 60 & 0.67 & 8 \\
5 & 9.0 & 5000 & 30 & 28 & 1.10 & 42 \\
\hline
\end{tabular}

$\mathrm{Hb}$ - hemoglobin $(\mathrm{g} / \mathrm{d} \mathrm{d})$.

WB - white blood cell (total).

G - granulocytes.

L - lymphocytes.

PI - platelets $/ \mathrm{mm}^{3}$.

HC - hairy cells. of patient 5 showed morphological similarity in neoplastic mononuclear cells, which had cytoplasmatic projections distributed across all the cell surface without polar predominance. A variable number of organelles was seen (Fig. 1).

Multiple mitochondrias of various sizes with well defined cristas were observed spreading on the cytoplasm and, rarely, in the perinucleolar area. Ribosomes tended to be numerous and dispersed in most cells. Rough endoplasmatic reticulum was scarce (Fig. 2). The Golgi apparatus, lysosomes, centrioles, microtubes and microfilaments were noted. Vacuoles were presented in most cells, containing structures of electron-dense vesicular or crystalline material (Fig. 3). There were no evident ribosomal lamellar complexes in any examined cells.

The nuclei had irregular membranes and displayed dense chromatine material adjacent to the membrane but were faint in the central area. In most sections, there were no apparent nucleoli but when encountered, they were single.

\section{DISCUSSION}

Patients 3, 4 and 5 exhibited hematological disturbances, including anemia (hemoglobin $7.2-9.0 \mathrm{~g} /$ $\mathrm{dl}$ ), leucopenia (white count $4200-5400 / \mathrm{mm}^{3}$ ) and thromocytopenia (platelet count $67000-110000 / \mathrm{mm}^{3}$ ), values that are comparable with those reported in previous studies $^{(1)}$.

The tartaric acid-resistant acid phosphatase test (TRAP) is important for identifying the acid phosphatase isoenzyme 5 which is present in hairy cells. This isoenzyme is not inhibited by tartaric acid, differing from the others that are inhibited by $\operatorname{TRAP}^{(7)}$. Patients 3,4 and 5 were TRAP positive and their cells showed a strong granular reaction. The number of hairy cells found in patients 1 and 2 was too low to reliably evaluate this test. However, the TRAP test was an important diagnostic tool for those patients who had a greater proportion of hairy cells.

In patients 1, 2 and 4, PAS was negative, probably due to the low level of neoplastic cells. Patient 3 was also PAS negative despite having a high percentage of hairy cells $(85 \%)$, suggesting a late cell maturation stage. In patient 5 , PAS was positive with a thin granular pattern.

The cytochemical evaluation did not include tests for alpha naphthyl acetate esterase and alpha naphthyl butyrate esterase despite their high sensitivity ${ }^{(8)}$, because they had not been carried out at the time of diagnosis. 


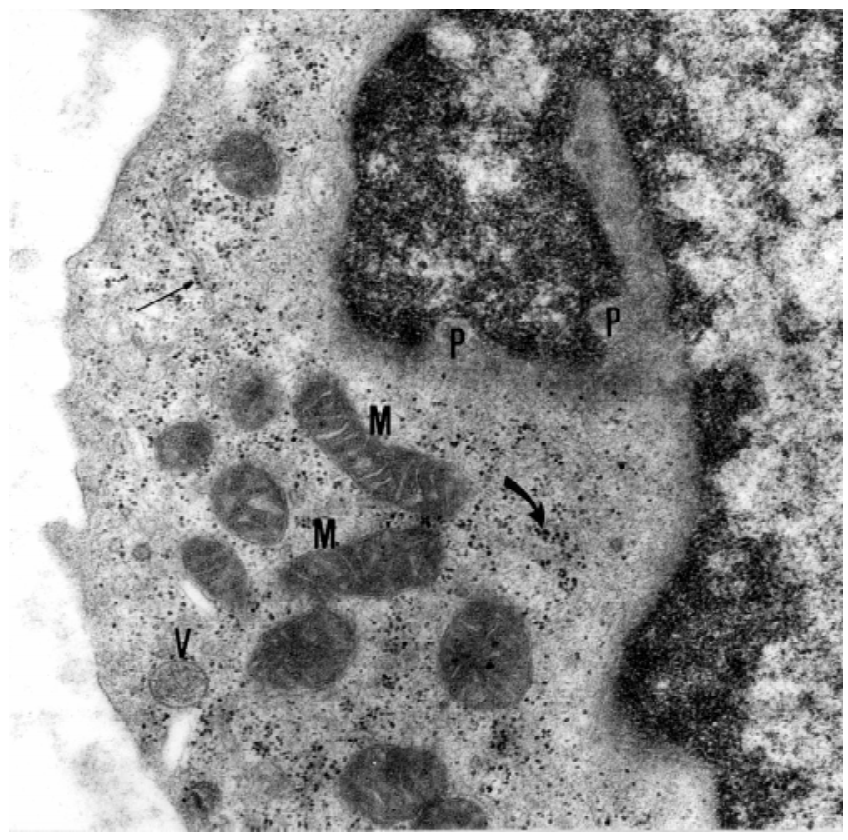

Figure 2 - Electron micrograph of hairy cell emphasizing mitochondrial structure with well - defined cristas (M), vacuoles with amorphous matter $(\mathrm{V})$, rough endoplasmic reticulum (small arrow), free ribosomes (large arrow) and nuclear porus (P). (X 50000)

Burns et al. ${ }^{(9)}$ stated that most hairy cells synthesize immunoglobulins that are expressed as the immunophenotype SIg. This test can define HCL as a proliferation of B cells. All the patients in this study were positive for SIg except case 1 whose level of hairy cells was below $1 \%$.

Demeter et al. ${ }^{(10)}$ showed that there are T-cell markers, such as $\mathrm{CD}_{3}$, that are specific to T lymphocytes at all stages of maturation (pan-T), whilst Palumbo et al. ${ }^{(11)}$ reported a similar specificity for $\mathrm{CD}_{19}$ for B lymphocytes. Patients 3 and 5, who had high levels of circulating hairy cells, showed a positive response to $\mathrm{CD}_{19}$ of $85 \%$ and $59 \%$ respectively, which is compatible with their B-cell origin. In the other patients, mature lymphocytes accounted for between $51 \%$ and $63 \%$ of those observed and were reactive to the monoclonal antibodies $\mathrm{CD}_{3}$ and $\mathrm{CD}_{7}$. This does not mean that these patients had hairy cells of T-cell lineage, because reactivity was only seen in normal mature lymphocytes and not in the hairy cells themselves. Therefore, we conclude that among patients with higher levels of circulating neoplastic cells, these cells are of B-cell origin.

Optical microscopy of peripheral blood and bone marrow aspirate showed hairy cells of medium size, and the nuclei were predominantly oval in shape with a chromatin pattern that was reticular. The cytoplasm was basophilic, pale and showed few granules. There were numerous fine hair-like projections arising from the cells which are associated with cell motility ${ }^{(12)}$.
Table 3

Cytochemistry and immunophenotypes of patients with $\mathrm{HCL}$, at the time of evaluation.

\begin{tabular}{|c|c|c|c|c|c|c|}
\hline Patient & TRAP & PAS & CD 3 (\%) & CD 7 (\%) & CD 19 & $\lg$ \\
\hline 1 & $\left({ }^{\star}\right)$ & $\left(^{*}\right)$ & 51 & 35 & 4 & $(-)$ \\
\hline 2 & $\left({ }^{*}\right)$ & $\left({ }^{*}\right)$ & 69 & 53 & $(-)$ & 4 \\
\hline 3 & + & - & 9 & $(-)$ & 85 & 11 \\
\hline 4 & + & 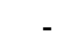 & 64 & 31 & 30 & 7 \\
\hline 5 & + & + & $(-)$ & $(-)$ & 59 & 28 \\
\hline
\end{tabular}

TRAP - Tartrate-resistant acid phosphatase.

PAS - Periodic acid-Schiff.

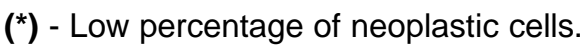

Morphological analysis using transmission electron microscopy, revealed that the frequency of hairy cells was directly proportional to the percentage of cells observed by optical microscopy. The hairy cells from peripheral blood and bone marrow aspirate were ultrastructurally similar.

Electron microscopy of the hairy cells showed that they possessed wide-based cytoplasmic projections. The Golgi complex was of intermediate size consisting of between 3 and 4 cisterns. Mitochondria were relatively few in number and were situated in the perinuclear region, characteristics that were not found by Daniel and Flandrin $^{(13)}$ or Katayama et al. ${ }^{(14)}$. Lysosomes, rough endoplasmic reticulum, ribosomes, centrioles and vacuoles

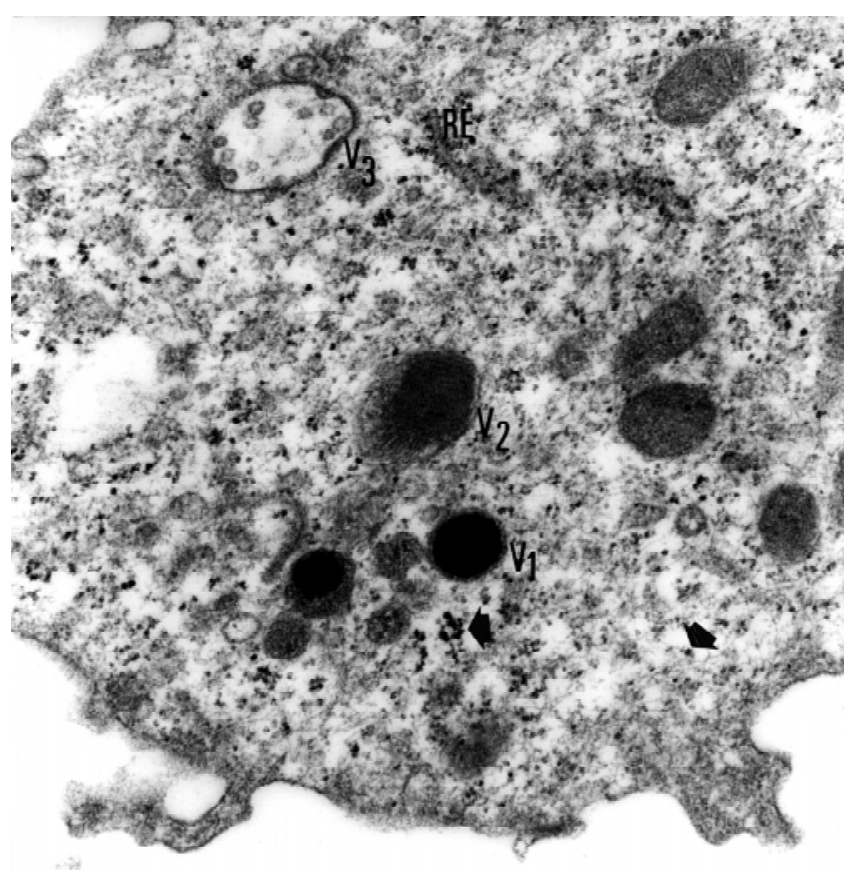

Figure 3 - Electron micrograph of hairy cell. Details of rough endoplasmic reticulum (RE), electron-dense vacuole (V1), crystalline vacuole (V2), intravacuolar vesicle (V3) and free ribosomes (arrow). (X 62500). 
(electron-dense with vesicular, crystalline content) were observed in variable quantities. We did not observe the ribosomal lamellar complex, probably due to the small sample size. This structure, of unknown function, was observed by Rosner and Golomb ${ }^{(15)}$ in $50 \%$ of hairy cells among 19 patients with HCL. The complex is not pathognomonic of HCL and occurs in other diseases such as multiple myeloma and acute monocytic leukemia.

The hairy cell nuclei had eccentric location and contained abundant condensed chromatin, in particular in the area adjacent to the nuclear envelope. Infrequent solitary small nucleoli were seen. Hairy cells obtained from bone marrow biopsy showed the same characteristics as those from peripheral blood and bone marrow aspirate, with the exception that the cytoplasmic villi of the hairy cells had interlocking cell borders.

It is important to point out that cases 1, 2 and 4, which had lower percentages of neoplastic cells and cases 3 and 5, with higher percentages, exhibited the same ultrastructural characteristics. This study shows the importance of electron microscopy, cytochemistry and immunophenotyping in the diagnosis of HCL and how these investigations complement the clinical evaluation and optical microscopy studies.

\section{Resumo}

Estudamos cinco pacientes com leucemia de células pilosas (LCP), diagnosticada nos últimos dez anos na Disciplina de Hematologia da Escola Paulista de Medicina. O principal objetivo foi analisar o valor da microscopia eletrônica de transmissão (MET) pela comparação deste método com os convencionais. Pacientes apresentavam no diagnóstico perda de peso, esplenomegalia e células pilosas (CP) no sangue periférico e medula óssea. As CP foram caracterizadas pela morfologia e resistência ao tartarato na reação de fosfatase ácida (FATR). Na época em que foram avaliados, a quantidade de CP variou de 1 a $85 \%$ da leucometria. Todos os pacientes tinham fenótipo B, excetuando-se dois nos quais FATR e imunofenótipo não puderam ser documentados devido ao baixo número de CP no sangue periférico e medula óssea. Projeções citoplasmáticas e ausência de complexo ribosômico lamelar foram os mais freqüentes achados na MET, mesmo nos pacientes com baixa porcentagem de CP. Baseado nestes achados concluímos que MET é um método eficiente no diagnóstico e evolução da LCP.

\section{REFERENCES}

1. Chang KL, Stroup R, Weiss LM. Hairy cell leukemia. Current status. Am J Clin Pathol 1992; 97 (5): 719-38.

2. Bouroncle BA, Wiserman BK, Doan CA. Leukemic reticuloendotheliosis. Blood 1958; 13: 609-29.

3. Golomb HM, Catovsky D, Golde DW. Hairy cell leukemia: a clinical review based on 71 cases. Ann Intern Med 1978; 89: 677-89.

4. Katayama I, Yang JPS. Reassessment of a cytochemical test for differential diagnosis of leukemic reticuloendotheliosis. Am J Clin Pathol 1977; 68: 268-72.

5. Burns GR, Cawley JC, Woman CP. Multiple heavy chains isotypes on the surface of the cells of hairy cell leukemia. Blood 1978; 2: 1132-47.

6. Variakojis D, Vardiman JW, Golomb HM. Cytochemistry of hairy cells. Cancer 1980; 45: 72-7.

7. Dacie JV, Lewis SM. Practical haematology. 6th edition. London: Churchill Livingstone; 1984: 84-86.

8. Faguet GB, Satya-Prakash KL, Agee, JF. Cytochemical, cytogenetic, immunophenotypic and tumorigenic characterization of two hairy cell lines. Blood 1988, 71: 422-9.
9. Burns GF, Woman CP, Cawley JC. Fluctuations in the T and B characteristics of two cases of T-cell hairy-cell leukemia. Clin Exp Immunol 1980; 39: 76-82.1980.

10. Demeter J, Pálóczi K, Földi J, Hokland M, Hokland D, Benczúr M, Lehoczky D. Immunological and molecular biological identification of a two case of T-hairy cell leukaemia. Eur J Haematol 1989; 43: 339-45.

11. Palumbo AP, Conadini P, Battaglio S, Omede P, Coda R, Boccadoro M, Pileri A. Dual rearrangement of immunoglobulin and T-cell receptor gene in a case of $\mathrm{T}$ cell hairy-cell leukemia. Eur J Haematolol 1991; 46: 71-6.

12. Catovsky MD, O’Brien M, Melo JV, Warde J, Brozovic M. Hairy cell leukemia (HCL) variant: an intermediate disease between $\mathrm{HCl}$ e B- prolymphocytic leukemia. Semin Oncol 1984;11 (4): 362-9.

13. Daniel MT., Flandrin G. The structure of abnormal cells in hairy cell (tricholeukocytic) leukemia, with special reference to their in vitro phagocytic capacity. Lab Invest $1974 ; 30$ : $1-8$.

14. Katayama I, LI CY, Yam LT. Ultrastructural characteristics of the "hairy cells" of leukemic reticuloendotheliosis. Am J Pathol 1972; 67: 361-70.

15. Rosner MC, Golomb HM. Lamella complex in hairy cell leukemia. Lab Invest 1980; 42 (2): 236-47. 